\title{
SPECIAL MEASURES' APPLICATIONS FOR VICTIMS AND VULNERABLE AND INTIMIDATED WITNESSES IN MALAYSIA: NEW FRONTIERS TO RIGHT TO A FAIR TRIAL?
}

\author{
Abidah Abdul Ghafar*
}

\begin{abstract}
Special treatment for victims and vulnerable and intimidated witnesses (VIWs) in a criminal process has developed over time in Western countries. The development of rights of victims' and VIWs and awareness on their needs and interests in pre-trial process and court proceedings has initiated the use of special measures' application. In England and Wales, some measures to lessen stress and trauma of such witnesses undergoing a criminal process were introduced into the legislations. Yet, as many other Asian countries, Malaysia developed her victims' policy only in 1990s and issues relating to the protection of VIWs were raised within the criminal justice system just recently. The tendency to put the standpoint into practice in the Malaysian legal system is demonstrated in the establishment of the Evidence of Child Witness Act 2007 (ECWA 2007) and the amendment of Section 272B of the Criminal Procedure Code. On the other hand, it is also arguable that special measures' applications for victims and VIWs will erode the right of defendants to a fair trial. This article aims at evaluating the current position of victims' and VIWs' rights and legal protection in the Malaysian criminal justice process. It elaborates on the rights of victims and other VIWs to special measures' applications in pre-trial process and court proceedings. Special measures such as live TV-link, screens, removal of formal attire, intermediaries and visual aids communication are potential to accommodate victims' and VIWs to give testimony in court. The use of video-recorded evidence is also evaluated as one of the means to facilitate traumatized victims and VIWs to give evidence and testimony. The possibility to enhance the

\footnotetext{
* Senior Lecturer, Faculty of Syariah and Law, Universiti Sains Islam Malaysia (USIM) Bandar Baru Nilai, 71800 Nilai, Negeri Sembilan, Phone No: +606 7988452; Email: abidah@usim.edu.my; abidghafar@gmail.com
} 
use of special measures'applications as one of the ways to advocate the right to a fair trial of victims and VIWs, without eroding the rights of the defendants, is also highlighted in this article.

Keywords: Vulnerable, intimidated, special measures.

\section{Introduction}

Special treatment for victims and vulnerable and intimidated witnesses (VIWs) in a criminal process has developed since the past 30 years in Western countries. The development of rights of victims' and VIWs and awareness on their needs and interests in pretrial process and court proceedings has initiated the use of special measures' application (SM application). In England and Wales, some measures to lessen stress and trauma of such witnesses undergoing a criminal process were introduced into the legislations.

Victims and witnesses are arguably the key persons in a criminal case but their rights and interests do not gain sufficient attention from the criminal justice players. A number of surveys and studies have researched the extent of the legislation and procedures for and the treatment of vulnerable and intimidated witnesses (VIWs) in the practice of the English criminal justice system ever since the establishment of the 1988 and 1991 Criminal Justice Acts. ${ }^{2}$ Most of the research that aimed to evaluate the application of special measures for VIWs either from the perspective of the victims and witnesses ${ }^{3}$ or that of the practitioners ${ }^{4}$ seems to agree on the importance of SM application to reduce the fear and distress experienced by VIWs in court.

2 Graham Davies and Elizabeth Noon, An Evaluation of the Live Link for Child Witnesses (London: Home Office 1991); Home Office, Speaking up for justice: Report of the Interdepartmental Working Group on the Treatment of Vulnerable or Intimidated Witnesses in the Criminal Justice System (London: Home Office 1998); Spencer JR. and Flin R, The Evidence of Children: The Law and the Psychology, (London: Blackstone Press 1990).

3 Becky Hamlyn et al., Are Special Measures Working? Evidence from Surveys of Vulnerable and Intimidated Witnesses, HORS 283 (London: Home Office 2004); Joyce Plotnikoff and Richard Woolfson, 'In Their Own Words: The Experiences of 50 Young Witnesses in Criminal Proceedings' (London: NSPCC/ Victim Support 2004).

4 Mandy Burton, Roger Evans and Andrew Sanders, Are Special Measures for Vulnerable and Intimidated Witnesses Working? Evidence from the Criminal Justice Agencies (London: Home Office 2006a). 
This article aims at evaluating the current position of victims' and VIWs' rights and legal protection in the Malaysian criminal justice process. It elaborates on the rights of victims and other VIWs to special measures' applications in pre-trial process and court proceedings. Special measures such as live TV-link, screens, removal of formal attire, intermediaries and visual aids communication are potential to accommodate victims' and VIWs to give testimony in court. The use of video-recorded evidence is also evaluated as one of the means to facilitate traumatized victims and VIWs to give evidence and testimony.

\section{Legislative Development of Special Measures' Application}

Having been under the English rule, Malaysia practises common law tradition and an adversarial court system. ${ }^{5}$ The foundation of criminal justice system in Malaysia is based on the underlying fundamental principle that an accused person is innocent until proven guilty. Article 11(1) of the United Nation Declaration of Human Rights 1948 in which Malaysia has ratified, provides that "Everyone charged with a penal offence has the right to be presumed innocent until proved guilty according to law in a public trial at which he has had all the guarantees necessary for his defence."6 In accordance with the presumption of innocence, the burden of proof in original circumstances is on the prosecution ${ }^{7}$, who have to gather and submit sufficient compelling evidence to the satisfactory of the judge. The trial process will involve the victims and other witnesses to give evidence orally in court, which normally warrants their physical presence in the courtroom.

As many other Asian countries, Malaysia also developed victims' policy in 1990s, when the reform of the criminal justice system

\footnotetext{
Abdul Rani Kamarudin, 'Between the Adversarial and the Inquisitorial Trial' [2007] 2 MLJ xi; [2007] 2 MLJA 11, at p. xiii

6 United Nations, United Nation Declaration of Human Rights 1948, http://www.un.org/ Overview/rights.html, accessed 25 June 2013; see also Article 6(2) of the European Convention for Protection of Human Rights 1953 and Article 14(2) of the United Nations International Covenant on Civil and Political Rights that "everyone charged with a criminal offence shall be presumed innocent until proved guilty according to law," although Malaysia is not a signatory to the Convention and Covenant respectively.

Evidence Act 1950, (Act 56), ss. 101-102
} 
spread in Asian region. ${ }^{8}$ The emergence for victim policy and victim support was influenced by the $4^{\text {th }}$ International Symposium on Victimology in Japan in 1982 and the United Nations' (UN) Declaration on the Basic Principles of Justice for Victims of Crime and Abuse of Power in 1985. ${ }^{9}$ Consequently, Malaysian criminal justice system embarked on protection of VIWs, particularly child witnesses.

The first legislation to reform the criminal process in Malaysia since 20 years is the Criminal Procedure Code (Amendment) Act 2006. The use of video conferencing and live television link in the examination of witnesses is introduced in Section 272B of this Act, which was gazetted and passed into law on 5 October 2006. Under this provision, "a person, other than the accused, may, with leave of the court, give video or live evidence through a live video or live television link in any trial or inquiry, if it is expedient in the interest of justice to do so". ${ }^{10}$ The tendency to put the standpoint into practice in the Malaysian legal system is further demonstrated in the establishment of the Evidence of Child Witness Act 2007 (ECWA 2007) $^{11}$.

These measures were originally proposed for application in proceedings of assault on, or an injury or a threat of injury, to persons, as provided under but not limited to sections 319 to 338 of the Penal Code. ${ }^{12}$ Their application was also recommended in proceedings of causing hurt for different purposes under sections 354 to 358 of the Penal Code. ${ }^{13}$ The proposal of application also extended to sexual offences relating to rape, incest, unnatural offences, and outraging modesty in the Penal Code, ${ }^{14}$ and in any other offences, if it deemed fit after consulting the Chief Justice and

\footnotetext{
8 Tatsuya Ota, 'Introduction: The Development of Victimology and Victim Support in Asia', Victims and Criminal Justice: Asian Perspective (Tokyo: Keio University 2003) 3.

9 Ibid.

${ }^{10}$ Criminal Procedure Code, (Act 593), s. 272B(1).

${ }^{11}$ Evidence of Child Witness Act 2007 (Act 676).

${ }^{12}$ Criminal Procedure Code (Amendment) Bill 2004, s. 272B(2)(a); relating to offences of hurt, causing hurt, voluntarily causing grievous hurt, causing hurt by dangerous weapons and etc.

13 that shall include assault and using criminal force to dishonour a person, to commit theft of property, to wrongfully confine a person and due to grave provocation.

${ }^{14}$ Criminal Procedure Code (Amendment) Bill 2004, s. 272B(2)(a) and (b).
} 
the Public Prosecutor. ${ }^{15}$ However, the proposed provision itemizing the applicability of Section 272B was later not included in the gazetted Criminal Procedure Code (Amendment) Act $2006^{16}$ leaving it silent as to the type offences that video conferencing and live-link shall be applicable as special measures. This provision covered not only child but also adult witnesses whom the court thinks will be vulnerable if they are compelled to give evidence in open court.

In August 2007, Malaysian criminal justice system embarked on another development via the passing of the ECWA 2007, which came into effect on 30 August 2009. This Act provided some protection specifically for child witnesses testifying in court, but not to include other witnesses likely subjected to intimidation and vulnerability. According to the Act, a child witness may, at any stage of a trial, give evidence from behind a screen separating him and the accused, by live link ${ }^{17}$ or by video recording ${ }^{18}$; or by any combination of the said manner. ${ }^{19}$ Evidence given via those manners is deemed to be of the same status as if being given in an open court. ${ }^{20}$

\section{Special Measures' Applications for Viws}

The measures that are normally being employed during the court proceedings are screens and live link. The use of screen in the courtroom will prevent the child witness from seeing or being seen by the accused, ${ }^{21}$ but shall not hinder him/her from being able to see and to be seen by the Magistrate or Judge, the prosecutor, the defence counsel and the interpreter. ${ }^{22}$ The use of screen and livelink while giving evidence is argued to give assurance to VIWs that they are not going to be 'harassed and bullied' and instil comfort

\footnotetext{
$15 \quad$ Ibid, s. 272B(2)(c)

16 Act A1274

17 ECWA 2007, (Act 676) s. 5; It is "a live television link or other arrangement whereby a child witness, while being absent from the courtroom or other place where the proceedings are being held, is able to see and hear a person in such courtroom or other place and to be seen and heard by the court, the prosecutor, the advocate for the accused or the child charged with any offence and the interpreter (ECWA 2007, s. 2).

18 In relation to a child witness, 'video recording' means "a video recording of the oral evidence of the child witness, in the form of an interview conducted between a police officer and the child witness, expressed upon any format, made with a view to its admission as evidence of examination-in-chief of the child witness" (ECWA 2007, s.2).

19 ECWA 2007, (Act 676) s. 3 (1)

$20 \quad$ Ibid, s. $3(2)$

$21 \quad$ Ibid, s. 4(1)

22 Ibid, s. 4(2)(a)-(d)
} 
to child witnesses so that they will be able to testify more freely and frankly. ${ }^{23}$ Other measures available to child witnesses include the use of intermediary in witness examination ${ }^{24}$, the leave for accompanying adults ${ }^{25}$ and the removal of formal court attire. ${ }^{26}$

The intermediary is used to communicate and explain questions put to the child witness and the answers given by the child witness in reply to those questions ${ }^{27}$ during the examination. The intermediaries are not allowed to prompt the child witnesses to answer the questions, influence their answers or disrupt the questioning of them. ${ }^{28}$ This rule also applies on accompanying adults for the child witnesses. ${ }^{29}$ An unrepresented accused shall only question a child witness through an intermediary, but not directly by himself. ${ }^{30}$ All of the above measures are provided by the ECWA 2007 to accommodate child witnesses to deliver their testimony. The application of these measures is hoped to lessen fear and distress of the child witnesses of confronting the defendants and facing the unfamiliar courtroom environment, which are possibly daunting and difficult.

\section{Witnesses in Need of SM Application: Who are they?}

Thus far, no specific definition for 'vulnerable witness' or explanation of 'vulnerability' in any legislation in Malaysia but the fear and distress of witnesses has considerably attracted attention of the practitioners. A number of categories of witnesses may be eligible for SM applications, namely:

\section{Child Victims/Witnesses}

The Malaysian Child Act $2001^{31}$ defines a 'child' as any person below the age of $18 .{ }^{32}$ This definition acquiesces to the provision of

\footnotetext{
23 Nithiyanantham Murugesu, 'The Role of the Law and the Courts in Preventing the Abuse of Children - The Malaysian Perspective' [2010] 5 MLJ cxxv; [2010] 5 MLJA 125 ECWA 2007 (Act 676), s. 8

Ibid, s. 9

Ibid, s. 10

Ibid, s. 8(2)

Ibid, s. 8(3)

Ibid, s. 9 (3)

Ibid, s. 8 (4)

Malaysia, Child Act 2001 (Act 611)

Child Act, (Act 611) s. 2
} 
the United Nations Convention on the Rights of the Child (UNCRC), which Malaysia have signed and acceded to. ${ }^{33}$ Notwithstanding the definition of 'child' in this Act, other words such as 'juvenile' and 'youthful offender', still exist in other legislations addressing minor or young offender in the criminal justice. In the ECWA 2007, 'child witness' is "a person under the age of sixteen years who is called or proposed to be called to give evidence in any proceedings...". ${ }^{34}$

The Human Rights Commission of Malaysia (SUHAKAM) has suggested that a terminology of words denoting a 'child', including 'young person', 'juvenile', 'infant' and etc. in other legislations need to be in consistent with the Child Act 2001. ${ }^{35}$ This need of standard definition is more significant in defining child witnesses, as it would determine the group who are entitled for special measures to be the same as those protected under the Child Act 2001. The discrepancies in setting the cut-off age for a child possibly influence the procedure to afford protection to them during the criminal process.

\section{Victims/Witnesses of Sexual Offences and Abuse}

Research shows that victims of incest and sexual abuse suffered from psychological trauma that would affect them for a long time or forever, as the perpetrators are the family members or individuals close to the victims. ${ }^{36}$ Victims react emotionally in three categories: first, sadness and crying, secondly, stable condition and thirdly, absence of grief accompanied by shame and frustration over the incident. ${ }^{37}$ Sometimes victims tend to hide their emotional distress in court $^{38}$ but their aftermath behaviour reflects the trauma. The trauma

\footnotetext{
33 A child refers to "every human being below the age of eighteen years unless under the law applicable to the child, majority is attained earlier" United Nations High Commissioner for Human Rights (UNHCHR), Article 1 of the Convention on the Rights of the Child (CRC), http://www.unhchr.ch/html/menu3/b/k2crc.htm, accessed 20 July 2013

34 ECWA 2007 (Act 676), s. 2

35 SUHAKAM, Convention on the Rights of the Child: Report of the Roundtable Discussion, (Kuala Lumpur: SUHAKAM 2005) 24

36 Nor Shafrin Ahmad and Rohany Nasir, 'Emotional Reactions and Behaviour of Incest Victims', no. 5 Procedia Social and Behavioral Sciences (2010) 1023-27, 1026

37 Ibid, 1025

38 Public Prosecutor v Tanwir bin Masri and Anor [2009] MLJU 0933, Criminal Appeal No (MT-5) 42-40-2008
} 
of the victims was translated from their emotions, physiology and behaviours, for example the victims were 'sad, ashamed, fearful, anger and hateful towards the abusers', ${ }^{39}$ and some were suicidal. ${ }^{40}$ Although the reaction and trauma are different between one victim and another, either of the emotional reaction categories would result in the victims' lack of cooperation, refusal and reluctance of sharing their stories with outsiders. ${ }^{41}$

Giving evidence against one's own family member or someone trusted or known to oneself in rape or incest cases is stressful, painful and distressing. Relating the incident of being raped to others would further be embarrassing, upsetting and confusing for victims and could lead to 'a repetition of victims' trauma' ${ }^{42}$. Child victims shall subsequently become witnesses when the cases are heard in court. Facing traumatic and awful experience when they have to relive the worst episode in their lives in front of outsiders, in unfamiliar courtrooms, would render them vulnerable. Adult victims and witnesses can be vulnerable in court due to intimidation from the defendants or others such as the defendants' family members.

Rape victims will be eligible for special measures if the court thinks that 'it is expedient in the interest of justice to do so' under the Criminal Procedure Code (Amendment) Act 2006. The legislation is yet silent in describing the circumstances that would render 'expedient' to do so. Shaikh Daud J (as he then was) however recognized the existence of trauma and re-victimization of rape victims in the trial where "rape victims especially young victims, go through traumatic experience at the time of the offence and later, and also at the trial more often than not they become the accused rather than the accuser". ${ }^{43}$

\section{Victims/Witnesses of Domestic Violence}

Victims of domestic violence are potentially vulnerable as they could suffer from several types of abuse including "physical

\footnotetext{
39 Shafrin Ahmad and Rohany Nasir, 1025

40 Ibid, 1026

$41 \quad$ Ibid, 1025

42 Ibid

43 Public Prosecutor v Yap Huat Heng [1985] 2 MLJ 414, 416; see also Amran bin Ahmad v Public Prosecutor [2005] MLJU 589.
} 
violence, psychological, emotional and verbal abuse, social abuse (enforced isolation), economic abuse (total control of finances) and sexual abuse (rape and coercion into sexual acts)". ${ }^{44}$ Domestic violence issues in Malaysia became the centre of discussion as early as in the 1980s. ${ }^{45}$ A national survey conducted by the Women's Aid Organisation (WAO) estimated that, in 1989, 1.8 million or 39 per cent of women aged above 15 had been physically abused by their partners, but only 909 cases were reported in that year. ${ }^{46}$

Reform of law and procedures have been significant in the success of SM applications for victims of domestic violence. The establishment of the WAO and the setting-up of the first centre for protection and shelter of abused women in Malaysia in 1982 pioneered the development of the reform process on domestic violence issues. It took an eleven-year effort through various workshops, campaigns and negotiations before the implementation of the Domestic Violence Act 1994 (DVA 1994) ${ }^{47}$ on the 1st of June 1996.

\section{Victims/Witnesses with Mental Impairment and/Or Physical Disability}

There are adults who can become vulnerable witnesses due to mental incapacity or physical disability. In this category, victims/ witnesses suffering from physical or mental incapacity, including mental disorder, significant learning disability, physical disorder and physical disability may need SM application to accommodate their appearance in court. Depending on the disability of victim/witness, an intermediary may need to be appointed for such witnesses in order to facilitate them to testify in court. Unlike physical deficiency, mental disabilities that can render the witnesses vulnerable are hard

\footnotetext{
44 Ian Marsh, John Cochrane and Gaynor Melville, Criminal Justice: An Introduction to Philosophies, Theories and Practice, (London: Routledge 2004) 98.

45 Amirthalingam Kumaralingam, 'A Feminist Critique of Domestic Violence in Singapore and Malaysia', Asia Research Institute Working Paper Series No. 6, (Singapore: NUS 2003) 15.

46 Rashidah Abdullah, Rita Raj-Hashim and Gabrielle Schmitt, Battered Women in Malaysia: Prevalence, Problems and Public Attitudes (A summary report of Women's Aid Organization Malaysia's National Research on Domestic Violence), (Kuala Lumpur: WAO 1995), 5.

47 Malaysia, Domestic Violence Act 1994 (Act 521).
} 
to recognise and raise issues of under-identification, as noted by other authors. ${ }^{48}$

In consequence to protecting VIWs and facilitating them with SM applications, issues relating to its effect against the right to a fair trial of the accused persons or defendants were raised within the criminal justice system just recently.

\section{Do SM Applications Erode a Fair Trial of Defendants?}

On the other hand, it is also arguable that SM applications for victims and VIWs will erode the right of defendants to a fair trial. The possibility to enhance the use of special measures' applications as one of the ways to advocate the right to a fair trial of victims and VIWs, without eroding the rights of the defendants, is also highlighted in this article.

An argument that SM applications go too far and prejudice the rights of defendants has raised an issue of whether defendants could also be vulnerable and were perhaps entitled to some protection. ${ }^{49}$ Special measures were afforded to child victims and witnesses whilst child defendants were excluded from similar protection. In the framework of adversarial trials, where the rights of the defendants are dominant, providing special measures for witnesses will counter this defendant-centred justice principle in some ways, balancing is deemed necessary.

\section{The Experience of England and Wales}

In England and Wales, the argument that young defendants could not benefit from the Act has also attracted a degree of sympathy

48 Ray Bull, 'Interviewing witnesses with communicative disability', in Handbook of Psychology in Legal Contexts, eds. Ray Bull and David Carson (Chichester: Wiley 1995); Rebecca Milne and Ray Bull, Investigative Interviewing: Psychology and Practice (Chichester: Wiley 1999); Rebecca Milne and Ray Bull, 'Interviewing by the police' in Handbook of Psychology in Legal Contexts, eds. David Carson and Ray Bull ( $2^{\text {nd }}$ edn, Chichester: Wiley 2003).

49 John R. Spencer, 'Criminal Procedure: the Rights of the Victim, Versus the Rights of the Defendant' in Reconcilable Rights? Analysing the Tension between Victims and Defendants, ed. Ed Cape (London: LAG 2004) 48. 
from the judges in $R$ v Camberwell Green Youth Court. ${ }^{50}$ While the procedure as it stood might not be appropriate for child defendants, depriving the child witnesses and victims of special measures were also not a right and proper way to treat the problem. Lord Rodger has pointed out on similar treatment of child defendants and child witnesses under the Vulnerable Witness (Scotland) Act 2004 that "there are no insuperable difficulties in the way of taking some such step" ${ }^{51}$ and this model may thus far provide some useful insights into how that might be achieved in Scotland.

Improving victims' rights has led to arguments about balancing the rights of child victims. ${ }^{52}$ It was argued in $R$ v Camberwell Green Youth Court that the mandatory presumption of Section 21(3) of the Youth Justice Criminal Evidence Act 1999 (YJCEA 1999) requiring that, except in the most exceptional circumstances, witnesses under 18 years $^{53}$ in cases involving sexual or violence offences must be examined-in-chief through video recordings and cross-examined through live link, was conflicting with the European Convention of Human Rights (ECHR)'s Article 6 of defendants' right to a fair trial. ${ }^{54}$ However, the appeal was dismissed. Their Lordships unanimously held that the defendants' right to a fair trial is not infringed instead the legislation upholds "sufficient safeguards to prevent any unfairness arising consistent with the principles laid down in European Court of Human Rights". ${ }^{5}$

Whether the police and Crown Prosecution Service (CPS) opt to facilitate special measures to obtain the best evidence from child witnesses is another issue. Burton et al. discovered that, in practice, the rebuttal on recorded interview took place against child witnesses in violent cases when the defendant is also a child. ${ }^{56}$ This happens because at that time these statutory measures were not similarly

\footnotetext{
50 Ibid, paras 39, 56-57

${ }^{51}$ Ibid, para 16

$52 \quad R$ v Camberwell Green Youth Court, ex p. D; R v Camberwell Green Youth Court, ex p. G [2005] UKHL 4, [2005] 2 Cr App R 1

53 YJCEA 1999 (As amended 2009)

${ }_{54}$ [2005] UKHL 4, [2005] 2 Cr App R 1, 9-10

55 Ibid, 2, 7-9, 16-18, 21-22

56 Mandy Burton, Evans R and Sanders A, 'Protecting children in criminal proceedings: Parity for child witnesses and child defendants' (2006b) 18(3) Child and Family Law Quarterly 397, 404.
} 
applicable to child defendants, even though the witnesses were actually considered vulnerable and eligible for special measures under the YJCEA 1999..$^{57}$ Therefore, the evidence-in-chief in cases involving defendants and witnesses below 17 (at that time) was rarely pre-recorded, as it is discretionary. ${ }^{58}$ The tendency to exclude child witnesses from the application of special measures was, inter alia, due to "the 'parity principle' application among older children, human rights issue of 'fairness' perception, (and) avoidance of more favourable treatment on child witness but the child defendant is similarly vulnerable". 59

The absence of SM applications for defendants has initially invited various criticisms. ${ }^{60}$ It was observed that the statutory denial of special measures for child defendants in Section 19(1) (a) of the YJCEA was countered by the needs of Article 6(3) (d) of the ECHR on the right of defendants to examine witnesses "under the same conditions as witnesses against him" and Article 40(iv) of the UNCRC. ${ }^{61}$ It was additionally in dispute with the judicial requirements ${ }^{62}$, as in $T \&$ $V$ v United Kingdom ${ }^{63}$, to make the courtroom procedure for child defendants less intimidating. Statutory protection measures for child and other vulnerable and intimidated defendants were impliedly favourable rather than depending on the common law judicial discretion. ${ }^{64}$ Legislative measures were suggested as to preserve a fair trial statutorily and uphold more justifiable conduct of the trial for all participants including the defendants, besides eliminating doubts in and contention with the YJCEA's provisions. ${ }^{65}$

\footnotetext{
Ibid

58 Ibid, 401

59 Ibid, 402-404

60 Hoyano LC, 'Striking a Balance between the Rights of Defendants and Vulnerable Witnesses: Will Special Measures Directions Contravene Guarantees to a Fair Trial?' [2001] Crim LR 948; Birch DJ, 'A Better Deal for Vulnerable Witnesses' [2000] Crim LR 223; Burton et al., Protecting Children (2006b) 406

${ }_{61}$ Hoyano, Striking a Balance [2001] 968

62 Ibid

63 (1999) 30 EHRR 121 (ECtHR)

64 Rhonda Powell, ' $R(D)$ v Camberwell Green Youth Court - child witnesses deemed to be in "need of special protection" and the European Convention' (2006) 18(4) Child and Family Law Quarterly 562

65 Ibid
} 
The disparity in protection has obviously occurred in cases of child and juvenile defendants whereas SM applications for child witnesses were arguably compatible with the right to a fair trial under Article 6 of the ECHR and consistent with the jurisprudence of the European Court of Human Rights. ${ }^{66}$ Therefore, depriving child victims and witnesses of special measures based on the parity principle was a questionable practice ${ }^{67}$ especially when the House of Lords in $R v$ Camberwell Green Youth Court ruled that protection for child victims should not be denied even if the same protection was previously not available to the defendants.

The issue of how such difficulties might be resolved has been addressed by the legislature, with the introduction of provisions under the Coroners and Justice Act 2009 (CJA 2009), allowing SM applications for child and vulnerable defendants. The conditions of eligibility ${ }^{68}$ are nonetheless quite different from that of VIWs under the YJCEA 1999 as it is not merely by virtue of age but other impairments beyond the fact of age alone must be exhibited. The recent development of the CJA 2009 has established the eligibility of using live-link and assistance of intermediaries for adult defendants suffering from significant mental disabilities. This CJA 2009 has also recognized witnesses to violent offences against person involving the use of firearms and knives as intimidated and automatically entitled for SM applications. These legislative measures are arguably potential to raise debates on receptive arguments under Article 6 ECHR and inconsistency in the treatment of VIWs. ${ }^{69}$

\section{Malaysian Scenario}

Similar occasion in Malaysia is where some would argue that providing special measures for VIWs of the prosecution will affect the rights of the defendants. It has been discussed earlier that providing measures that prohibit face to face confrontation may affect the defendants' ability to confront the witnesses in a way which they perceive to be advantageous to their interests. In this

\footnotetext{
66 Hoyano, Striking a Balance [2001] 968

67 Burton et al. Protecting Children (2006b) 406; Birch, A Better Deal [2000] 242; Hoyano, Striking a Balance [2001] 968

68 CJA 2009, ss. 33A(2) and 33BA(2)

69 Laura CH Hoyano, 'Coroners and Justice Act 2009: special measures directions take two: entrenching unequal access to justice’ (2010) 5 Crim L.R. 345-367
} 
regard, the defendants' interests may be compromised, but their rights are not as rights need to be distinguished from interests. This is an issue which had been presented to the practitioners in a study ${ }^{70}$ to get their perspectives.

Most of the practitioners from 25 respondents in the study, including some defence counsels ${ }^{71}$, were of the views that SM applications for VIWs do not affect the rights of the defendant in general. ProsecutorAG5 considered that live link will not affect the defendant's rights in a trial, because the witness is within sight of the defendant through the monitor screen.

In my opinion it does not [affect the right of the defendant]; ...they also can see and hear how the witness responds; because we have one screen for the prosecution, the counsel has one screen on his own, and the judge also has his or her own screen. So there is no issue of tampering with the evidence whatsoever; because the things are in the court itself. It is just the separate room. (Prosecutor-AG5)

The concern of Prosecutor-AG5 is not so much with the right to confrontation but rather with the issue of tampering with the witnesses' evidence. Prosecutor-AG6 argued that, although a face-toface confrontation is absent in a live-link trial, it does not depreciate other procedures for examining the witness. Examination-in-chief, cross-examination and, on certain occasions, re-examination, are performed as usual on that particular witness by means of live camera and monitor screen.

They are still subjected to the normal examination by all the parties concerned. So, there's nothing wrong with having the special measures being afforded to this kind of witnesses. (Prosecutor-AG6)

\footnotetext{
70 Abidah Abdul Ghafar, 2011, Legal Protection for Vulnerable and Intimidated Witnesses (VIWs) from the Perspective of Human Rights: An Analysis in the Malaysian Criminal justice System, PhD Thesis, Leicester, United Kingdom

71 Counsel-DC1, Counsel-DC3 and Counsel-DC5
} 
It is possible to relate the notion of Prosecutor-AG6 on live link to remote link and screens, as the normal examination procedure of witnesses can be carried out, but further evaluation needs to be made of the application of video-recorded evidence. However, none of the practitioners in the study ${ }^{72}$ discussed this, as this measure has yet to achieve stand in practice.

It is further presumed by Prosecutor-AG6 that the defendants cannot justifiably object to SM applications as witnesses afforded with these measures are usually known to the defendants, and defendants are already aware of the grounds of application:

Now, if the defendant would want to object then let him object and we'll hear the grounds of objection, why are you objecting to this application you see? It's a twoway thing. We can make the application. You can file yours... You can put your objection; and if you were to object... You tell us why you are objecting to this; because you'll be in court. You'll be listening to this particular witness testifying; and you know this witness. (Prosecutor-AG6)

To assume that SM applications are usually given to those witness who are known to the defendants, reflects an exclusionary approach, which will inadvertently circumscribe the identification of VIWs and the application of special measures, especially amongst adult witnesses. Many adult witnesses are potentially vulnerable and the failure of the criminal justice system to identify them has been proved in many studies. ${ }^{73}$

However, Prosecutor-AG6 agreed that the SM applications could still have an impact on the defendants in the sense that their use can influence the court's impression of the defendants. That, which can be inferred by the court from the acts and reactions of the witness in the identification of accused/defendant procedure within a trial

\footnotetext{
Abidah Abdul Ghafar, Legal Protection (2011)

73 Bull (1995); Milne and Bull (1999) and (2003); Hamlyn et al. (2004) Mandy Burton, Evans R and Sanders A, 'Implementing Special Measures for Vulnerable and Intimidated Witnesses: The Problem of Identification' [2006c] Crim LR 229; Burton et al. (2006a) and (2007).
} 
with live link or screen, will favour the prosecution evidence. The inference would be that the witness's demeanour of avoiding a face to face confrontation with the defendant is evidence in itself against the defendant. Prosecutor-AG6 explained that the possible inference made by the court could create a negative impression of the defendant:

The court observes now that this particular witness is adamant, that she doesn't want to see. What does that show? That shows that this guy is really the perpetrator. He really did it to the daughter or else the daughter would not be refusing to even look at him. That will be the impact on the defendant. The impression of the court is that; 'you' must have done it, mustn't you; or else why would your own daughter not even want to see your face on TV?; on the screen she would not even see! She's so scared even to that extent. We have convinced her "no, your daddy is not here. He will just be appearing on the screen; your TV screen". Still she refused. (Prosecutor-AG6)

If this kind of impact occurs in trials with SM applications, it is likely to affect the right of the defendants to a fair trial and, in this regard, to the presumption of innocence, whereas the objective of applying special measures is merely to assist witnesses in court without compromising the rights of the defendants. The possibility of negative inferences about the defendants is more apparent if the justification submitted by the prosecutors to the court in support of their application is based on witnesses' fear of seeing the defendants, or the existence of intimidation. Prosecutor-AG6's viewed that the defendants should not object as they already know what the witnesses are afraid of.

The defence perspective shows that, for various reasons, not all SM applications are challenged. SM applications will not be objected to by the defence counsels if they do not prejudice the rights of the defendants; i.e. when they feel unthreatened. In this regard, CounselDC3 stated that objections by the defence in a proceeding in general are made on two grounds: first, on any breach of law of procedure; and second, on the practitioner's approach and style in examining the witness: 
Objection or not from the defence counsel is related to two aspects: firstly, whether the measure transgresses any legal aspects or procedures; and secondly, in terms of the style of the prosecutor. If the conduct or the questions forwarded contravene the legal aspects and evidence, for example in terms of relevancy, in terms of guiding the witness, leading and so on, I will usually object. But if it involves tolerable matters and the prosecution also informs us in a gentlemanly manner from the beginning, my stand is that there is no need to object. (Counsel-DC3)

SM applications are also viewed as not contravening the rules and laws of evidence, unlike coaching the witnesses, which is expressly prohibited by the laws of evidence. ${ }^{74}$ Counsel-DC3's response indicates this:

However, let the witness relate. So long as the narration is not coached or scripted by the prosecution, let her/ him describe. We will have opportunity to crossexamine her/him. (Counsel-DC3)

This implies that the defence counsels are unlikely to object if the application does not affect the rights of the defendants. ProsecutorAG2, Prosecutor-AG4, Prosecutor-AG5 and Prosecutor-AG6 stated that they have never experienced an objection by the defence counsel to SM applications. Although Prosecutor-AG7 has experienced objections from the defence, thus far the court has not upheld the objections; therefore her applications for special measures have so far always been granted by the court. The lack of objection from the defence reflects that the interests of defendants are safe and unthreatened despite the SM applications. This coincides with the notion that SM applications do not affect the interests of defendants; hence do not contravene to the right of fair trial.

The discretionary provision of Section 272B of the CPC has left the decision to afford SM applications for adult witnesses to the court. In this regard, Counsel-DC1 does not consider that SM

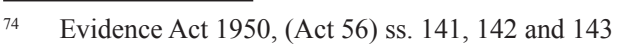


applications will affect the right of the defendant as the matter is left to the discretion of the court, which takes a neutral stance in the adversarial proceedings:

So, whether protecting the right of the witness has an impact on the right of the defence, actually you have to keep in mind that, at the end of the day, the goal of doing this is to uphold justice; just in the administration of criminal law. So, the court will be very careful not to violate any rights available to the defendant. (CounselDC1)

The defence does not feel affected, as leaving the matter to the discretion of the court might in a way safeguard the right of the defendants to a fair trial. This is also supported by Counsel-DC3, who believed that the court should play a significant role in balancing the rights of both sides to a fair trial and should not be 'excessive' in giving protection to prosecution witnesses. This is consistent with the opinion of Prosecutor-AG6 on the impact of special measures on the neutrality and impartiality of the court.

The mandatory SM applications for child witnesses under the ECWA 2007 is nonetheless acceptable to the defence counsels since the strict requirement on the need for corroboration ${ }^{75}$ of the admissibility of children's evidence is understood. ${ }^{76}$ To the contrary, mandatory requirement for corroboration of unsworn evidence of child witness, which is still operative in Malaysia, albeit the abolishment in other jurisdictions, ${ }^{77}$ may deteriorate the enhancement of victims'/ VIWs' rights, and become anti-climax to the development of SM applications.

On the other hand, a viewpoint from the defence on SM applications indicates that "confrontation" should not only be significant for defendants, but also for the victims/VIWs, with respect to the strength of the case and potency to win. The counsels raise the issue of confidence and ability to confront the defendant in the courtroom

75 Ibid, s. $133 \mathrm{~A}$

76 Public Prosecutor v Gurdial Singh Pretum Singh \& Ors [2003] 1 CLJ 37

77 This requirement has been abolished in English, Canadian, Australian, New Zealand and American laws. See Hoyano and Keenan (2010) 690-698 
as the 'true test' of whether the witness is making a true allegation against the defendant. In other words, the witness's ability to testify without SM applications should be regarded as strengthening the case. This was also highlighted by Prosecutor-AG1 earlier.

There are counsels who consider the protection of the rights of witnesses as being in direct opposition to the protection of the defendants' rights. Defence counsels also viewed that allowing SM applications should be made as a 'trade-off' in return for certain procedures that can enhance the rights of the defendants; in other words, as a "bargaining tool". As a balancing point, Counsel-DC4 suggested that both parties should do something for one another. In this sense, if the prosecution feel that they need to apply for special measures for their VIWs, they should be more transparent by allowing a discovery process for the defence in the criminal trial. In other words, Counsel-DC4 promoted a 'win-win' situation between the prosecution and the defence:

...but let us do both at the same time. You help the other side by changing the law, making criminal trial more transparent, more open, less trial by ambush; and at the same time you protect them and make their cases faster; and then it will coincide and meet and let the judge decide. (Counsel-DC4)

Although it is argued that the testimony is given live and in person by the witnesses via live link or behind screens, in the presence of the defendants and counsels, Counsel-DC4 still contended that it is important to ensure that both prosecution and defence are placed on the 'same level playing field'.

Putting the prosecution witnesses in diametrical opposition to the defendants seems to accord them the same right to a fair trial. Witnesses', particularly victims', right to a fair trial is arguably disregarded ${ }^{78}$. Counsels' view that allowing SM applications should be made as a 'trade-off' with the rights of the defendants signifies a recognition that SM applications could provide a fair trial for the victims and other VIWs, without compromising that of the

78 Abidah Abdul Ghafar, Legal Protection (2011), 25-30 and 47-50 
defendants. Counsel-DC5 reacted to the need to have a fair trial, not only for the defendants, but for all parties to the proceeding, stating that "everybody should be given an opportunity to voice their views, to defend themselves... likewise a fair trial must be, fair to everybody'. ${ }^{79}$ Allowing SM applications to facilitate witnesses in giving testimony in the proceedings, establishes a fair trial for victims/VIWs by embedding their rights and interest in the account of criminal justice system, but will still not secure the same right and status quo to them as similar to that of the defendants.

\section{Conclusion}

SM applications in Malaysia are acknowledged by most of the practitioners in the above study as capable of enhancing victims' and VIWs' rights without eroding the rights of the defendants. The lack of objections from the defence counsels demonstrates that SM applications do not affect the strength of their cases and, to a certain extent, possibly work in favour of the defence. Some of the evidence rules in the adversarial system might be against the defendants' interests but they do not necessarily encroach, erode or affect the defendants' rights; this applies similarly to the SM applications for VIWs. However, the existence of a 'balancing approach' is shown in the above study through the notion of allowing SM applications as a 'trade-off' for certain procedures in favour of the interests of the defendants, such as disclosure procedure. ${ }^{80}$ In short, some defence counsels do see SM applications as a 'bargaining tool' to secure and to show that it is detrimental to their interests.

On the other hand, this research has shed light on the insight of some criminal justice practitioners on SM application for VIWs. Those practitioners, particularly the prosecutors, have acknowledged the notion that SM applications should only be provided for witnesses, not defendants, despite the potential needs and interests of the latter ${ }^{81}$ Studies have suggested ${ }^{82}$ and has already been introduced in

\footnotetext{
79 Counsel-DC5

80 See Abidah Abdul Ghafar, Legal Protection (2011) 258-264

81 The ECtHR suggested that it may be appropriate to appoint intermediaries for defendants with communication needs in SC v United Kingdom (2005) 40 E.H.R.R. 10; [2005] 1 F.C.R. 347 (European Court of Human Rights). See also Burton et al. (2006b) 402-404; Powell R (2006) 562; Hoyano [2001] 948; Birch [2000] 241-242

82 Roberts et al. (2005); Hoyano (2010)
} 
England and Wales ${ }^{83}$ that the enhancement of VIWs' rights in terms of SM applications is not limited just to prosecution witnesses, but may also be extended to defendants and defence witnesses, and this will not infringe victims' and VIWs' rights. ${ }^{84}$ However, this is not yet the case in current Malaysian practice. Given the scenario, it is hoped that the objective of SM applications in securing facilities for VIWs in courts proceeding will earn better achievement of justice through understanding and commitment of criminal justice practitioners.

\section{References}

Abdul Rani Kamarudin, 'Between the Adversarial and the Inquisitorial Trial' [2007] 2 MLJ xi; [2007] 2 MLJA 11.

Abidah Abdul Ghafar, Legal Protection for Vulnerable and Intimidated Witnesses (VIWs) from the Perspective of Human Rights: An Analysis in the Malaysian Criminal justice System, PhD Thesis (Leicester, 2011).

Amirthalingam Kumaralingam, 'A Feminist Critique of Domestic Violence in Singapore and Malaysia', Asia Research Institute Working Paper Series No. 6, (Singapore: NUS 2003) 15.

Birch DJ, 'A Better Deal for Vulnerable Witnesses' [2000] Crim LR 223.

Bull R, 'Interviewing witnesses with communicative disability', in Handbook ofPsychology in Legal Contexts Edited by Ray Bull and David Carson (Chichester: Wiley 1995).

Burton M, Evans R and Sanders A, 'Implementing Special Measures for Vulnerable and Intimidated Witnesses: The Problem of Identification' [2006c] Crim LR 229.

84 Michael Tonry, 'Rebalancing the criminal justice system in favour of the victim': the costly consequences of populist rhetoric' in Hearing the Victim: Adversarial Justice, Crime Victims and the State, eds. Anthony Bottoms and Julian V. Roberts (Portland and Devon: Willan Pub. 2010) 72-103, 76. 
Burton M, Evans R and Sanders A, 'Protecting children in criminal proceedings: Parity for child witnesses and child defendants' (2006b) 18(3) Child and Family Law Quarterly 397, 404.

Burton M, Evans R and Sanders A, Are Special Measures for Vulnerable and Intimidated Witnesses Working? Evidence from the Criminal Justice Agencies (London: Home Office 2006a).

Davies G and Noon E, An Evaluation of the Live Link for Child Witnesses (London: Home Office 1991).

European Convention for Protection of Human Rights 1953, Article $6(2)$.

Hamlyn B, Phelps A, Turtle J and Ghazala Sattar, Are Special Measures Working? Evidence from Surveys of Vulnerable and Intimidated Witnesses, HORS 283, (London: Home Office 2004).

Home Office, Speaking up forjustice: Report of the Interdepartmental Working Group on the Treatment of Vulnerable or Intimidated Witnesses in the Criminal Justice System (London: Home Office 1998).

Hoyano LC and C Keenan, Child Abuse: Law and Policy Across Boundaries (Oxford: OUP 2010).

Hoyano LC, 'Coroners and Justice Act 2009: special measures directions take two: entrenching unequal access to justice' (2010) 5 Crim L.R. 345-367.

Hoyano LC, 'Striking a Balance between the Rights of Defendants and Vulnerable Witnesses: Will Special Measures Directions Contravene Guarantees to a Fair Trial?' [2001] Crim LR 948.

Ian Marsh, John Cochrane and Gaynor Melville, Criminal Justice: An Introduction to Philosophies, Theories and Practice, (London: Routledge 2004) 98. 
Milne R and Bull R, 'Interviewing by the police' in Handbook of Psychology in Legal Contexts Edited by David Carson and Ray Bull ( $2^{\text {nd }}$ edn, Chichester: Wiley 2003).

Milne R and Bull R, Investigative Interviewing: Psychology and Practice (Chichester: Wiley 1999).

Nithiyanantham Murugesu, 'The Role of the Law and the Courts in Preventing the Abuse of Children - The Malaysian Perspective' [2010] 5 MLJ cxxv; [2010] 5 MLJA 125.

Nor Shafrin Ahmad and Rohany Nasir, 'Emotional Reactions and Behaviour of Incest Victims', (2010) 5 Procedia Social and Behavioral Sciences 1023-27.

Plotnikoff J and Woolfson R, 'In Their Own Words: The Experiences of 50 Young Witnesses in Criminal Proceedings' (London: NSPCC/ Victim Support 2004).

Rhonda P, 'R (D) v Camberwell Green Youth Court - child witnesses deemed to be in "need of special protection" and the European Convention' (2006) 18(4) Child and Family Law Quarterly 562.

Roberts P, Cooper D and Judge S, 'Monitoring success, accounting for failure: The outcome of prosecutors' applications for special measures directions under the Youth Justice and Criminal Evidence Act 1999' (2005) 9(4) Intl J Evidence Proof 269.

Spencer JR, 'Criminal Procedure: the Rights of the Victim, Versus the Rights of the Defendant' in Reconcilable Rights? Analysing the Tension between Victims and Defendants, ed. Ed Cape (London: LAG 2004) 37-51.

Spencer JR. and Flin R, The Evidence of Children: The Law and the Psychology (London: Blackstone Press 1990).

SUHAKAM, Convention on the Rights of the Child: Report of the Roundtable Discussion, (Kuala Lumpur: SUHAKAM 2005). 
Tatsuya Ota, 'Introduction: The Development of Victimology and Victim Support in Asia', Victims and Criminal Justice: Asian Perspective (Tokyo: Keio University 2003) 3.

Tonry M, 'Rebalancing the criminal justice system in favour of the victim': the costly consequences of populist rhetoric' in Hearing the Victim: Adversarial Justice, Crime Victims and the State, Edited by Anthony Bottoms and Julian V. Roberts (Portland and Devon: Willan Pub. 2010) 72-103.

United Nations High Commissioner for Human Rights (UNHCHR), Article 1 of the Convention on the Rights of the Child (CRC), $\mathrm{http}: / / \mathrm{www} . u n h \mathrm{chr} . \mathrm{ch} / \mathrm{html} / \mathrm{menu} 3 / \mathrm{b} / \mathrm{k} 2 \mathrm{crc} . \mathrm{htm}$, accessed 20 July 2013.

United Nations, United Nation Declaration of Human Rights 1948, http://www.un.org/Overview/rights.html, accessed 25 June 2013.

United Nations, United Nations International Covenant on Civil and Political Rights, Article 14(2). 